\title{
The Schurer-Stancu approximation formula revisited
}

\section{DAN BĂRBOSU}

\section{ABSTRACT.}

Some properties of the Bernstein-Schurer fundamental polynomials are recalled and a new proof for the remainder term of Schurer-Stancu approximation formula is presented.

\section{REFERENCES}

[1] Agratini, O., Aproximare prin operatori liniari, Presa Universitară Clujană , Cluj-Napoca, 2000 (Romanian)

[2] Bărbosu, D. and Barbosu, M., Some properties of the fundamental polynomials of Bernstein-Schuler, Bul. St. Univ. Baia-Mare, Ser. B, MatematicăInformatică, 18 (2002), No. 3, 133-136

[3] Bărbosu, D., Schurer-Stancu type operators, Studia. Univ. Babeş-Bolyai, XLVIII (2003), No. 3, 31-35

[4] Bărbosu, D., On the Schurer-Stancu approximation formula, Carpathian J. Math., 21 (2005), No. 1-2, 7-12

[5] Bărbosu, D., Polynomial approximation by means of Schurer-Stancu type operators, Ed. Univ. de Nord, Baia-Mare, 2006

[6] Floater, M. S., On the convergence of derivatives of Bernstein approximation, J. Approx. Theory , 134 (2005), 130-135

[7] Schurer, F., Linear positive operators in approximation theory, Math. Inst. Techn. Univ. Delft: Report, 1962

[8] Stancu, D. D., Asupra unei generalizări a polinoamelor lui Bernstein, Studia. Univ. Babeş-Bolyai, 14 (1969), No. 2, 31-45 (Romanian)

Department OF MATHEMATICS AND COMPUTER SCIENCE

Faculty of SCiences North University Center at Baia Mare

TECHNICAL UNIVERSITY OF ClUj-NAPOCA

VICTORIEI 76, 430122 BAIA MARE, ROMANIA

E-mail address: barbosudan@yahoo.com 